\title{
POSTHARVEST DISINFESTATION OF NEW DISEASES ON ASPARAGUS
}

\author{
D.R. BEASLEY ${ }^{1}$, C.M. HORLOCK ${ }^{1}$ and L-H CHEAH ${ }^{2}$ \\ ${ }^{I}$ DPI\&F, Applethorpe Research Station, PO Box 501, Stanthorpe, \\ Qld 4380, Australia \\ ${ }^{2}$ Crop \& Food Research, Private Bag 11600, Palmerston North, New Zealand \\ Corresponding author: cheahl@crop.cri.nz.
}

The effect of six postharvest disinfectants (sodium hypochorite, chlorine dioxide 'Expel', bromo-chlorodimethyl hydantoin 'Nylate', peroxyacetic acid and hydrogen peroxide 'Tsunami', chlorine dioxide 'Vibrex' and chlorine) and hot water treatment $\left(48^{\circ} \mathrm{C}\right.$ for $\left.5 \mathrm{~min}\right)$ on in vitro spore germination and germ-tube elongation of Puccinia asparagi, Phomopsis asparagi and Colletotrichum gloeosporioides spores was evaluated. These three pathogens, which cause rust, phomopsis stem blight and anthracnose, respectively, were detected in Queensland in 2000 but have not been recorded on asparagus in New Zealand. Spores of these fungal pathogens were mixed with the different disinfectant solutions, spread onto water agar plates and incubated at $25^{\circ} \mathrm{C}$ for 24-48 h. The effect on spore germination and germ-tube elongation was determined using a light microscope. Nylate, Vibrex, sodium hypochorite and chlorine were highly effective and completely inhibited spore germination of Phomopsis asparagi and Colletotrichum gloeosporioides. Nylate, Tsunami and sodium hypochlorite were most effective against Puccinia asparagi. The hot water treatment also significantly reduced spore germination and germ-tube elongation. These results indicate that several of the postharvest disinfectants tested could be used for disinfecting the spores of these three fungal pathogens on asparagus spears before they are imported to New Zealand or transported to other states in Australia.

\section{INFLUENCE OF CROP ROTATION ON SOIL-BORNE DISEASES OF POTATO CROPS IN MANAWATU}

\author{
L-H CHEAH and A.T. MARSH \\ Crop \& Food Research, Private Bag 11600, Palmerston North, New Zealand \\ Corresponding author: cheahl@crop.cri.nz.
}

A survey of 50 potato growers in the Manawatu region was carried out in 2004 to assess the effect of different crop rotations on soil health and soil-borne diseases. From the response, most growers had a rotation cropping system in place with the exception of one grower who has grown potatoes in the same area for five consecutive seasons. The most common crops used in rotation with potatoes were pasture, wheat, barley, maize and squash. In general it was found that the most common crop rotation used by the growers is three seasons of pasture followed by one potato crop. Growers believed that this practice contributed to better soil health and reduced the incidence of soil-borne diseases. Therefore, this practice was included as one of the treatments in a long-term rotation trial. The aim is to assess the most effective long-term crop rotation practice for soil health and soil-borne disease management. 